\title{
On Anaya's Bless Me, Ultima and Becoming a Lifelong Reader, and How I Nearly Blew It as a Teacher: An Extended Testimonio
}

\author{
RENÉ SALDAÑA, JR., \\ TEXAS TECH UNIVERSITY
}

\section{On BeComing a LifELong ReAder}

My experience with Rudolfo Anaya's Chicano novel Bless Me, Ultima (1972) should date back to the mid-1980s when I was a student in a deep South Texas high school where the school's population consisted largely of Mexican American and Mexican students. This is the same time in adolescents' lives when they are introduced to what could possibly be course-changing novels. J.D. Salinger's Catcher in the Rye comes to mind. So do S.E. Hinton's The Outsiders, Ayn Rand's Atlas Shrugged, and Harper Lee's To Kill a Mockingbird. All stories that so impact readers that they, from then onward, recognize the value of Literature throughout their lives.

So great is the impact because adolescent readers somehow identify with the story being recounted: an event in the narrative strikes them as meaningful because they have had a comparable, significant experience or a character reflects some aspect of their own nature, some teens even crediting a book with saving their lives, as a point of fact (an idea long championed by Dr. Joan Kaywell (2015), a sexual abuse survivor, who states that books literally saved her life and so why could the same not work for teenagers struggling with their "own situations"?).

Whatever the reason, adolescent readers see and hear themselves on the pages of these seminal stories. I did not, however. For the duration of my junior and high school years, I read de Maupassant, Bradbury, Fitzgerald, Faulkner, Shakespeare, and so many others. None of whom were telling my story. Middle school age is critical in the making of life-long readers. Ebe (2012) writes that tweens and young teens "are expected to read increasingly difficult academic texts" (p. 180). Freire (1998) describes reading as "an intellectual, difficult, demanding operation" (p. 19). Imagine how the problem of reading is further compounded for a student who is already struggling at the word level and he/she also fails to make any personal connections to the story. There is nothing to drive the student to dig into the story, much less to continue on to the end. That struggling reader is in danger of becoming a reluctant- or non-reader. During my junior high and high school years I was that student.

I should have been made to read Anaya so I could have approached Ultima like I did all the other assigned texts: grudgingly at first. I would have taken it home to trudge through the week's allotted reading. As they say, 
hindsight is 20/20, but I truly think this novel could have elicited a different response from me than did Dickens. I could have opened it to the first page and read, "Ultima came to stay with us the summer I was almost seven" (p. 1). My curiosity piqued, I would have recognized that the old woman, one of the main characters of the novel, has a Spanish name, meaning "the last" (or, as is more likely the case in this novel, the term refers to rank: "the ultimate," "of the highest order," or "the one"). Later, she is called "la Grande" (p. 3), the great one, the elder, and that too, in addition to the reverence for the viejitos, would have been familiar to me as a Mexican American.

I would have been thrown off my reading game, so to speak, because this was Spanish I was seeing in an assigned text instead of English like I was accustomed to reading in the classroom. My grandparents and my parents all spoke Spanish in our homes. How many times did I hear my own mother say, " $i Q u e ́$ lástima" as does the mother in this novel (p. 2). Spanish: a familiar and familial language. A language, for all intents and purposes, prohibited to us in the South Texas classroom of those days.

The boy down the street from me was called Toño, the diminutive of Antonio, the novel's narrator and another main character. Had I been given the chance to read this book, I could have imagined my friend's face on the pages of Anaya's novel. His face and the narrator's cuento would have made the story accessible to me.

Later in the story, Antonio, his mother, and his sisters, are on their way to El Puerto, where the Luna family farm is located. On the way, the family "passed the church and crossed our foreheads" (p. 45). Though I was not Catholic, I was used to to making this same gesture when on a school trip that took us in front of the Basilica of Our Lady of San Juan del Valle in South Texas. Despite being "a Protestant" (p. 102), I would have easily identified with this sign of the cross in reverence to God and respect for my schoolmates' faith, and I would have taken note of it in Ultima, as well.

Never mind the countless stories I grew up hearing about curanderas or healers (p. 4), brujas or witches (p. 76) who "turn to owls and fly at night" (pp. 11 \& 102), and La Llorona (p. 26). On a side note, I myself visited with a curandera as a child, and I will swear until the day I die I heard La Llorona's wailing in my neighborhood more than once.

From word one, literally, I would have read in wonderment because for the first time ever I would have seen and heard myself and my culture presented on the pages of a class-sanctioned text. That the teacher, the authority figure in the classroom, would have intentionally selected this text would have made the world of difference to me, a Mexican American looking for a reason to get back into the reading act. I could have fallen in love with Literature much earlier in life. I would not have wasted all those years thinking that reading's purpose was to make the grade, to score a college scholarship, a chore otherwise. I would have, instead, known books as witnesses to cultures and sources of strength and healing much like Ultima's role is in Anaya's novel.

\section{(A Parenthetical summary of Anaya's Novel)}

Antonio's mother, who is a Luna (moon), dreams of her youngest son to follow in her brothers' footsteps, who are men of the land. If not a farmer, then "perhaps a priest" (p. 8). The boy's father, who is a Márez (seas), imagines 
that his son will be just like his side of the family: vaqueros, men of the llano, who felt "the freedom their spirits needed" riding on horseback across the broad expanse (p. 2). Haunted by his parents' conflicting desires, Antonio must discover for himself that path that will lead him to his true fate.

Ultima, providentially it seems, comes to live with them on their little farm on the hill overlooking "the magic of the green river" (p. 10) to "spend the last days of my life here," she tells the boy (p. 11). In truth, she has come to undertake the responsibility of walking alongside him, teaching him, providing his soul "her careful guidance" (p. 14). He must learn that the short years he spends with Ultima provide him: "a man's destiny must unfold itself like a flower, with only the sun and the earth and water making it blossom, and no one else meddling in it" (p. 213), a lesson hard-learned.

Despite his young age, Antonio is witness to a great deal of suffering. Weighing on his heart are his brothers' absence (the war has taken them to fight an enemy on a foreign land and upon their return find the trappings of home too restrictive and leave behind the hill to make their way in life), the souls of men (Lupito, who commits the mortal sin of murder is, himself, shot to death without absolution from the church), the great hatred of man (rage-filled Tenorio seeks revenge on Narciso), injustice (the same Tenorio, literally, gets away with murder, causing Antonio to question man's unfair dealings and God's lack of a just rejoinder), and his best friend's untimely death (Florence drowns in Blue Lake). In the end, it is these experiences and his ability to process others' pain empathically that teach him that "life is filled with sadness when a boy grows to be a man. But as you grow into manhood you must not despair of life, but gather strength to sustain you" (p. 234).

\section{BACK to on BECOMING A LIFELONg READER}

Would that I had been given the opportunity to read Ultima. But I was not assigned this book. Instead, I read these first sentences: "In my younger and more vulnerable years my father gave me some advice that I've been turning over in my mind ever since" (Fitzgerald, 1995, p. 5), "You don't know about me, without you have read a book by the name of 'The Adventures of Tom Sawyer,' but that ain't no matter" (Twain, 2003, p. 3), and "It was a pleasure to burn" (Bradbury, 2013, p. 1), none of which grabbed my attention.

Years later, well into my master's studies at Clemson University, I was working on my thesis on the sanctified and sanctimonious characters in the novels of James Baldwin, one of the only writers whose stories I nominally identified with by that age. His Go Tell It On the Mountain (2013) served as my introduction to writing by people of color, the closest I had come to reading myself in a book. One weekend, I stepped into a favorite bookstore that sold both new and used titles. Displayed on a pyramid shelf facing the entrance was the book that would put me on the path to becoming a lifelong reader. It was Sandra Cisneros' The House On Mango Street (1991). The story of young Esperanza Cordero was my very own. Though I was not a young Latina girl growing up on Southside Chicago, and though I did not have in common any lived experiences with her, I saw and heard 
myself in Esperanza. I could not contain my excitement. There was only one person I wanted to share this thrilling experience with: my sister.

To make a long story short, I traded my copy of Mango Street for my sister's copy of Ultima. She'd gotten to read the novel in high school, and fortunately for me, she'd never returned it to the English department. She had been part of our high school's college prep program, while I hadn't. Thus, the disparity in reading options.

I finally got my turn at Anaya, and now I had found myself in two books: Cisneros' Mango Street that fortuitously led to Ultima. Today, I cannot believe my luck: not one but two home run books. These titles are described as such because they are "one's first positive reading experience, the one that sets you on the reading path" (Von Sprecken, Kim, \& Krashen, 2000, n.p.). Freeman and Freeman (2004) describe these sorts of books as "ones that [a reader] connects with, books that draw on [his/her] background and culture" (p. 7). Vélez-lbáñez and Greenburg (2005) introduced us to the term "funds of knowledge" in 1992 (p. 47), referring to the wealth of experiences a child owns and brings to the academic table. Freire (1987, p. 35) suggests educators should invite a child to read his/her world before being capable of truly comprehending the word (p. 35).

\section{Culturally Relevant Literature AND Its Benefits}

Simply, a culturally relevant text is one in which struggling readers discover "familiar elements" (Freeman \& Freeman, 2004, p.7) that then help readers better "understand who they are" (p. 8). Rosenblatt (2005) calls this process a "framework into which to fit the ideas as the words unfurl" (p. 73). In other words, they are seeing and hearing themselves represented fairly and accurately on the pages of a book translating into validation of self and culture both (Bishop, 1990). The moment this occurs, the likelihood of students wanting to repeat this reading experience again grows exponentially. When they see the value in reading themselves in stories, they will have an easier time learning the ins-and-outs of the reading craft, and just as importantly, they will also recognize the worth of reading in general. From then onward, they will know how to engage any and all texts.

\section{Cultural Validation Through Conquest}

If "reading is," as Freire (1998) says, "searching for, seeking to create an understanding of what is read" (p. 19), then absent a genuine reason for engaging literature (that is, understanding or comprehending what a minoritized student is confronting on the page) readers are more apt to lose interest in the reading act. When children are introduced to characters whose stories and lives do not resemble in the least the readers', they begin to grow accustomed to this cultural erasure. Excluded from literature selected purposefully by the educational system, minoritized students are thereby forbidden to join the very important discussions taking place at the literary table. Worse, they may not even know that they have a right to a place at the table. They then are labeled by the same system that would erase them as "struggling." Freire (1998) writes, educators "participate in [students'] development. We may help them or set them back in their search" (p. 33). At that point, educators either perpetuate this cycle of illiteracy based on repeated cultural exclusion, or we break from the cycle by 
introducing these readers, who are in danger now of becoming reluctant or non-readers, to one text after another until they see themselves reflected in class-sanctioned literature.

On the one hand, the decision to prohibit a child from an authentic search for self within the school experience "constricts the ways in which identities are negotiated between teachers and students and the opportunities for learning that culturally and linguistically diverse students experience" (Cummins, 2000, p. 4). "To educate the whole child in a culturally and linguistically diverse context," Cummins further argues, "it is necessary to nurture intellect and identity equally in ways that, of necessity, challenge coercive relations of power" (p. 6). But "nurture" is too tame a word. Freire (2000) calls it what it is: validation or visibility through "conquest" (p. 47).

\section{EDUCATION AS DANGEROUS}

Cummins (2000) himself later writes, "When schools and individual educators refuse to play their preordained part in the social order, education becomes dangerous" (p. 10). Freire (2000) writes, "To surmount the situation of oppression, people must first critically recognize its causes, so that through transforming action they can create a new situation, one which makes possible the pursuit of a fuller humanity" (p. 47). That is to say, the systemicallyminoritized or -erased must take charge of their own struggle that "begins with [a] recognition that they have been destroyed" (p. 68). Cummins (2000) adds: "To create a future we need to rupture the past" (p. 10). Beautifully dangerous this destruction that is guaranteed to rise transformed, legitimized, validated, there before our very eyes.

On the other hand, research on the use of culturally relevant literature in the minoritized classroom indicates that "[w]hen teachers use culturally relevant books, students understand the books more fully, and, as a result, become more engaged in their reading. When students become more engaged in texts, they are motivated to read more" (Freeman and Freeman, 2004, p. 7), resulting in what Freire (1987) terms "cultural production" (p. 142). Cultural production involves "specific groups of people producing, mediating, and confirming the mutual ideological elements that emerge from and reaffirm their daily lived experiences" (p. 142). This includes but is not limited to introducing a wider audience of Mexican American to a culturally seminal text such as Ultima.

It follows that if Mexican American students are more genuinely engaged in the act of reading that they will also take a more active role in their cultural production. A clearer understanding and ownership of one's cultural identity equates to visibility (the opposite of erasure). Freire (2000) states it best: "The solution is not to 'integrate' [minoritized students] into the structure of oppression, but to transform that structure so that they can become "beings for themselves'" (p. 74). Using culturally relative literature in the classroom will only serve to validate Mexican American students' personal and cultural identities, resulting in them pulling their chairs up to the literacy table and participating actively and visibly.

The great danger, though, lies in these readers never getting this opportunity. 


\section{How I Almost Blew It As A Teacher}

Freire (1998) asserts that "education is a political act" (p. 63). That means educators are, by definition, political actors who consciously and subconsciously make decisions daily about how to best serve their students' academic needs, about how to transform their literacy classrooms into the most optimal and equitable learning experience for them all, about how make of literacy "a set of cultural practices that promotes democratic and emancipatory change" (Freire, 1987, p. 141).

One would think that when I returned to South Texas after finishing up my grad studies at XU to start teaching $10^{\text {th }}$ grade English at the very school I had graduated from not long before, and knowing the sheer delight I had experienced reading Cisneros and Anaya (and soon after Denise Chávez, Gary Soto, and Rolando Hinojosa-Smith), that I would have made certain to give my students that same thrill at reading themselves in a class-sanctioned text. I was one of them, after all. I knew that the majority of my Mexican American students were most likely as disengaged from literature as I had been. That they could benefit from discovering themselves culturally on the pages of a book assigned. That I would have broken ranks with my more experienced colleagues, who had themselves been teaching from the same list of required texts for decades. Including during my high school years. But I did nothing of the kind.

I taught literature the only way I knew how, the way I had seen my professors do for the previous several years of my undergraduate and graduate education: the lecture during which I covered the material assigned as dictated to me (and therefore onto my students) by the long-established curriculum. Our required reading list mirrored the one imposed on me only years prior. Nothing had changed, except that I was now the teacher. And I took the easy out: I taught Bradbury, de Maupassant, and O. Henry.

I was convinced I could make a difference in these students' reading lives, unlike my own teachers had. I had a masters in literature, after all. I knew literature. I felt that I could do a much more effective job of teaching these authors and their work than my colleagues since I was younger, much more hip than they. I would sell the idea to my charges that reading was the key to academic success.

I failed miserably that first year. I saw it in the students' glazed-over eyeballs, heard the boredom in their voices as I invited them to volunteer to read "from where so-and-so left off through the last full sentence on the next page." Nothing I did worked for them.

\section{Almost Blowing It Is Not Blowing It for Real: A Chance at Redemption}

My second year, I agreed to teach at a newly-established $9^{\text {th }}$ grade accelerated campus. We were promised the cream of the gifted and talented crop. They were struggling in the traditional classroom, so a move here would benefit them. We were also told we would have free reign to create curriculum that would challenge these students in non-traditional ways. What we got were what one concerned parent back then called "the bottom of the barrel kids." She was right, in a sense. We inherited gang members, both boys and girls, students who found 
themselves constantly in one kind of trouble or another, students who had no desire to finish high school and who were just biding their time until they were old enough to quit. Her child was not any of these, she said. He was just too easily distracted. He did not belong with us, she insisted. We convinced her to give us a chance. But now we had to fulfill our promise that we would take all our students from the place they found themselves academically to a higher level.

\section{NOt A TOTAL FAILURE}

That first year at this accelerated campus, we saw our role as academic activists in support of our students. In the English/Language Arts classroom, we restructured the reading list, for one. Our "revolutionary" idea was wellworn by then; I am talking about the mid-90s, so culturally-responsive and multicultural pedagogies had already been tested and proven to work (Anzaldúa, Banks, and Gay, to name a few). We read sections of Mango Street, we introduced students to Gary Soto's poetry, and because several students were affiliated with gangs, I suggested we teach "The Somebody" by Danny Santiago (1992), about a boy named Chato who imagines himself a major player on Shamrock, the street he lives on in his barrio in East L.A. He is more Quixote than OG, but my students were nevertheless able to identify with the gang and tagging cultures. Back then I was not conducting research, so I do not have hard data showing that exposure to culturally relevant literature made a difference in these students' lives. But since then I have collected mostly anecdotal evidence of the veracity of this approach (Saldaña, 2010, 2018).

In the years that followed, I mixed the more traditional texts with culturally relevant ones. I was still not researching, so the attention I paid to the effects of one compared to the other was minimal and mostly based on my recollections. I did, however, start to pay better attention to my students' "funds of knowledge," so to one $7^{\text {th }}$ grade boy who showed interest in learning about the business world I gifted lacocca: An Autobiography (lacocca \& Novak, 1984). A $9^{\text {th }}$ grade boy, who was a reluctant gang member, borrowed and never returned my copy of Luis J. Rodriguez's Always Running: La Vida Loca, Gang Days in L.A. (1993). To a $10^{\text {th }}$ grader who was a self-described outsider I loaned my copy of Jack Kerouac's On the Road (1957). They all read their respective titles voraciously, and they were all willing to talk about them during and after their reading experiences. I will never credit my teaching abilities for their successes. They thrived solely based on their lived experiences and how they resembled those presented in these books.

When I started teaching at the university level in the same area, I was asked to teach a children's and adolescent literature class to students in the teacher-prep program. I had seen firsthand how our South Texas students literacy lives had blossomed as a result of reading culturally relevant literature. So I drew up my reading list that included the work of David Rice, Pat Mora, Carmen Tafolla, Viola Canales, Xavier Garza, Victor Martinez, and several others. My university students were amazed at how much of this literature existed already, and many were disappointed that this was the very first time they had read anything that told their stories. Several, who tested these and other titles during their field placements or with their families, shared their own stories of how 
their students or children loved these stories that could have been set in the Rio Grande Valley, that employed code-switching, and that they had experienced themselves (like quinceañeras, bodas, tamaladas, etc.).

Had I thought about it, I would have asked if any of them had ever read Anaya's Bless Me, Ultima. I would be curious to know how far or how little we had moved in deep South Texas in that regard.

\section{Conclusion: Carrying Pinches of OUR CUlture With Us}

Toward the end of that first summer after Ultima comes to live with Antonio's family, he and Ultima spend their mornings "gathering the wild herbs and roots for her medicines," their "magic harvest" (p. 36). During those times, Antonio becomes "strangely aware of a new world opening up and taking shape for me" (p. 36).

Antonio's time with Ultima is well-spent. They "walked together in the llano and along the river banks to gather herbs and roots for her medicines." The boy learns the names of plants and flowers, of trees and bushes, of birds and animals." More importantly, he says, he

learned from her that there was a beauty in the time of day and in the time of night, and that there was peace in the river and in the hills. She taught me to listen to the mystery of the groaning earth and to feel complete in the fulfillment of its time. (p. 14)

Had he never been able to spend this time with Ultima, Antonio would never have taken notice of the beauty in the details of his daily, lived existence. But it is in this quiet time that he learns from her that each plant and herb and animal has a name and about their connection to him and vice versa. His new, lived experiences add a dimension of awareness to his life.

Discovering oneself on the pages of a text is similarly a wondrous occurrence. It is earth-shaking, though never earth-shattering. Struggling readers now see life through a more expansive lens. Their lives undergo change like Antonio's.

One day, Antonio is out on the llano with Ultima. He is studying her intently as she collects her herbs. Upon careful reflection, he notes the meticulousness with which the curandera handles the herbs:

Ultima's soft hands would carefully lift the plant and examine it. She would take a pinch and taste its quality. Then she took the same pinch and put it into a little black bag tied to a sash around her waist. She told me that the dry contents of the bag contained a pinch of every plant she had ever gathered since she began her training as a curandera many years ago. (p. 37)

It is no mistake why Louise Rosenblatt $(2005$, p. 7) calls reading "an event." A genuine "transaction involving a particular reader and a particular pattern of signs, a text, and occurring at a particular time in a particular context" (p. 7) leaves an impression on a person. A single book can impact a reader positively or negatively. Whatever the case might be, we readers carry with us those reading experiences for a lifetime much like Ultima does her herbs. Like her herbs, culturally-validating book experiences can be curative, enriching, and empowering. They are "a cure for everything." They are spices for our "beans and meat." They are for eating "in the shade by the river" (p. 37). 
Culturally relevant texts, in short, serve as witnesses to our students' struggles and their stories of survival. They tell their cuentos, and in so doing, like Ultima's owl, these stories keep watch over all that happens to them and who they are.

Can one book save a child's life? In my case, in a sense, yes. Had I not rediscovered a love for reading in graduate school when I happened upon Mango Street and later Ultima, my life today would be significantly different than it is. Had I not unearthed the treasures that the reading act holds, I would not have become a writer. I would not have dreamt of the possibility of publishing my own cuentos in The Jumping Tree (2001), which fictionalizes my own coming of age. I would not have known that the story of my formative years was worth telling, much less putting to paper.

My hope is a simple one: that Mexican American students coming up will share the same joy that I felt when I read myself in stories, that, as a result of reading culturally relevant texts, they will look at their lives and culture in the same way as Antonio does when he first spends time with Ultima:

I saw for the first time the wild beauty of our hills and the magic of the green river. My nostrils quivered as I felt the song of the mockingbirds and the drone of the grasshoppers mingle with the pulse of the earth. The four directions of the llano met in me, and the white sun shone on my soul. The granules of sand at my feet and the sun and sky above me seemed to dissolve into one strange, complete being. (pp. 10-11)

My simple hope is that they will fall in love with the reading act, but that they will not have to wait as long as I did, nor that they have to rely on pure chance that they would one day stumble upon their own Mango Street and Ultima.

My simple hope is that seeing and hearing themselves in literature is the rule rather than the exception. 


\section{REFERENCES}

Anaya, R. A. (1972). Bless me, Ultima: a novel. Berkeley, CA: TQS Publications.

Baldwin, J. (1988). Go tell it on the mountain, Giovanni's room, The fire next time. New York, NY: Quality Paperback Book Club.

Bishop, R. (1990). Mirrors, windows, and sliding glass doors. Perspectives: Choosing and Using Books for the Classroom, 6(3). Retrieved from https://scenicregional.org/wpcontent/uploads/2017/08/Mirrors-Windows-and-Sliding-Glass-Doors.pdf

Bradbury, R. (2013). Fahrenheit 451. New York, NY: Simon \& Schuster Paperbacks.

Cisneros, S. (1989). The house on Mango Street. New York, NY: Vintage Books.

Cummins, J. (2000). Language, power and pedagogy: Bilingual children in the crossfire. Tonawanda, NY: Multilingual Matters.

Ebe, A. E. (2012). Supporting the reading development of middle school English language learners through culturally relevant texts. Reading \& Writing Quarterly, 28, 179-198. doi: 10.1080/10573569.2012.651078

Fitzgerald, F. S. (1995). The great Gatsby. New York, NY: Scribner Paperback Fiction/Simon \& Schuster.

Freeman, Y. \& Freeman, D. (2004). Connecting students to culturally relevant texts. Talking Points, April/May, 7-11.

Freire, P. (1998). Teachers as cultural workers: letters to those who dare teach. Boulder CO: Westview Press.

Freire, P. (2000). Pedagogy of the oppressed. NY: The Continuum International Publishing Group Inc.

Freire, P. \& Macedo D. (1987). Literacy: reading the word and the world. Westport, CT: Bergin \& Garvey.

Kaywell, J. (2015). How books save lives [video file]. Retrieved from https://www.youtube.com/watch?v=Bqxlfo6qXCw

Moll, L.C., Amanti, C., Neff, D. \& Gonzalez, N. (1992). Funds of knowledge for teaching: Using a qualitative approach to connect homes and classrooms. Theory Into Practice, 31(2), pp. 132-141.

Rosenblatt, L. (2005). Making meaning with texts: selected essays. Portsmouth, NH: Heinemann.

Saldaña, R. (2010). Writing, teaching, and researching: an interview with René Saldaña, Jr. Journal of Adolescent and Adult Literacy, 53(8), 688-690.

Saldaña, R. (2018). Hook them with leyendas: mixing in some spooky tales to get kids reading. Literacy Today, May/June, 14-15.

Santiago, D. (1992). The Somebody. In Edward Simmen (Ed.), North of the Rio 
Grande: The Mexican-American experience in short Fiction (pp. 212-221). New York, NY: Mentor.

Twain, M. (2003). The adventures of Huckleberry Finn. New York, NY: Barnes \&

Noble Books.

Vélez-Ibáñez, C. \& Greenburg, J. (2005). Formation and transformation of funds of

knowledge. Reprinted in Funds of knowledge: theorizing practices in households, communities and classrooms. Edited by Norma González, Luis C. Moll, \& Cathy Amanti. New York, NY: Routledge. pp. 4769.

Von Sprecken, D., Kim, J., \& Krashen, S. (2000). The home run book: can one positive reading experience create a reader? California School Journal, 23.2, 8-9.

RENÉ SALDAÑA, JR., is Associate Professor of Language, Diversity, and Literacy Studies in the College of Education at Texas Tech University in West Texas. He is also the author of several titles for young adults, including The Jumping Tree, The Whole Sky Full of Stars, A Good Long Way, and Heartbeat of the Soul of the World. He is presently working on a biography in verse about Muhammad Ali and Howard Cosell. 